\title{
PLACENTAL INTERCHANGE. II. COMPARISON OF THE TOTAL BASE CONCENTRATION OF THE FETAL AND MATERNAL BLOOD AT PARTURITION
}

\author{
By H. E. THOMPSON, JR., AND W. T. POMMERENKE \\ (Department of Obstetrics and Gynecology, University of Rochester, School of Medicine and \\ Dentistry, Rochester, New York)
}

(Received for publication April 11, 1938)

Although the literature on the permeability of the placenta to many substances either of a metabolic or foreign origin is extensive, there is a paucity of data on comparisons of maternal and infant total base. In 1920 Stander and Tyler (1) reported identical values for the ash of maternal and fetal plasma, while Lévy-Solal, Dalsace, and Gutman (2) in 1934 reported the maternal and fetal plasma ash to be 7.97 and 9.25 grams per liter respectively. Eastman, Geiling, and De Lawder (3) found the total serum base of fetal and maternal serum to be low and stated that the normal adult total base was about 154.0 m.eq., while that of fetal blood was about 148 m.eq.

In the present study, the total base was determined simultaneously on samples of maternal venous, umbilical arterial, and umbilical venous plasma from blood obtained at the time of delivery.

\section{METHODS}

The subjects of this study were 30 parturient women and their respective normal appearing, newborn children, No discriminations as to age, race, previous history of the mother or the weight or sex of the infant were made. However, infants born in a debilitated condition and their respective mothers were not among those on whom data is reported here. As has been noted in a previous paper (4), values for maternal blood are regarded as approximating the fasting level because little food is ordinarily consumed during labor.

Collection of blood. At delivery of the infant, the umbilical cord was cut and blood collected from the umbilical arteries and the umbilical vein. The blood was received into a centrifuge tube to which $10 \mathrm{mgm}$. of heparin were added to prevent clotting. In only a very few instances was there clot formation. Shortly after collection of fetal blood, blood was withdrawn without stasis from a maternal arm vein, and treated to prevent clotting as described above. All blood collections were generally completed within about 5 minutes. Centrifugalization for 20 minutes' at moderate speed was then carried out, and the hematocrit determined. All volumetric apparatus employed in the total base analysis was calibrated by the weight method before beginning this study. In order to measure accurately $0.2 \mathrm{cc}$. of plasma, $1 \mathrm{cc}$. of plasma was diluted to $10 \mathrm{cc}$., and $2 \mathrm{cc}$. aliquots of this solution were used in each analysis. Each determination was made in duplicate and 2 blanks were run with each dialysis, 8 cells being run at a time.

Determination of total base. The rapid and efficient electrodialysis method for total base determination developed not long ago by Keys (5) was employed with gratifying results. The mercury employed was purified by vacuum distillation. Checks indicated that stock distilled water was as satisfactory as that obtained by distillation with phosphoric acid. Using as control a salt solution containing 130.5 m.eq. of sodium and $4.5 \mathrm{~m}$.eq. of potassium, the mean of 7 consecutive determinations of total base was found to be $134.6 \pm 0.7$ m.eq. The deviation of the mean from the expected value was -0.3 per cent. Since plasma solutions are far more complex in character than a simple salt solution, several determinations were made in triplicate on plasma solutions in order to determine how precise the method was under the conditions of these experiments. The results are indicated in Table I.

The data show that the difference between the lowest and highest values for 3 determinations on the same plasma solution varied from 0.1 to $3.1 \mathrm{~m}$.eq. with an average value of 1.8 m.eq. Each determination is the mean of two analyses, the agreement of which is typical, excepting for values in determination E-1. The precision in this instance is less than for any value reported in Table II.

TABLE I

Precision in analyses of plasma solutions for total base

\begin{tabular}{|c|c|c|c|c|c|c|c|}
\hline \multirow{2}{*}{ Subject } & \multicolumn{2}{|c|}{$\begin{array}{l}\text { Determina- } \\
\text { tion } 1\end{array}$} & \multicolumn{2}{|c|}{$\begin{array}{l}\text { Determina- } \\
\text { tion } 2\end{array}$} & \multicolumn{2}{|c|}{$\begin{array}{l}\text { Determina- } \\
\text { tion } 3\end{array}$} & \multirow{2}{*}{$\begin{array}{c}\text { Difference } \\
\text { between } \\
\text { highest } \\
\text { and lowest } \\
\text { means }\end{array}$} \\
\hline & & Mean & & Mean & & Mean & \\
\hline $\begin{array}{l}\text { A } \\
\text { B } \\
\text { C } \\
\text { D } \\
\text { E }\end{array}$ & $\begin{array}{l}154.6 \\
155.0 \\
151.6 \\
151.9 \\
151.9 \\
153.2 \\
152.9 \\
151.6 \\
151.4 \\
145.5\end{array}$ & $\begin{array}{c}154.8 \\
151.8 \\
152.6 \\
152.3 \\
148.4\end{array}$ & $\begin{array}{l}153.6 \\
152.9 \\
151.4 \\
152.0 \\
150.4 \\
151.9 \\
149.9 \\
149.9 \\
148.5 \\
148.0\end{array}$ & $\begin{array}{c}153.3 \\
151.7 \\
151.2 \\
149.9 \\
148.3\end{array}$ & $\begin{array}{l}153.7 \\
153.7 \\
153.4 \\
154.2 \\
154.4 \\
150.4 \\
150.4 \\
149.0 \\
147.8\end{array}$ & \begin{tabular}{|l}
153.7 \\
153.4 \\
154.3 \\
150.4 \\
148.4
\end{tabular} & $\begin{array}{l}1.5 \\
1.7 \\
3.1 \\
2.4 \\
0.1\end{array}$ \\
\hline Average & & 152.0 & & 150.9 & & 152.0 & 1.8 \\
\hline
\end{tabular}


As Keys has pointed out, the presence of preformed ammonia in the blood is a factor that must be recognized in the estimation of total base on an unashed plasma sample. In a study of 120 pregnant women, Bock (6) found the preformed ammonia in the second stage of labor to be $0.501 \mathrm{mgm}$. per $100 \mathrm{cc}$. or about $0.3 \mathrm{~m}$.eq. per liter, an insignificant fraction of the total base. No data have been found for fetal preformed ammonia in the blood at term. The probability of ammonia formation in the blood on standing was eliminated as a source of error because analyses were begun within an hour after the samples were obtained. No use of ammonium reagents for cleaning or analytical purposes was permitted in the laboratory where the analyses were performed.

Tests on aqueous solutions of heparin, corresponding in concentration to that of heparinized blood, showed that this anticoagulant contained no detectable base by electrodialysis.

\section{RESULTS}

The results of this investigation are summarized in Table II. The hematocrit readings are perhaps somewhat elevated but this is probably due to the heparin. Marx (7) has pointed out that the hematocrit on heparinized blood is about 10 per cent higher than when the determination is carried out with oxalate.

Before going on to a discussion of the import of the statistical summary, a consideration of some of the individual results may be of value. It is interesting to note that in only one instance

TABLE II

Comparison of maternal and infant total base

\begin{tabular}{|c|c|c|c|c|c|c|c|c|c|c|c|c|}
\hline \multirow{3}{*}{ Patient } & \multirow{3}{*}{ Age } & \multirow{3}{*}{ Para } & \multicolumn{6}{|c|}{ Maternal and infant values at delivery } & \multicolumn{3}{|c|}{$\begin{array}{l}\text { Maternal values in the } \\
\text { puerperium }\end{array}$} & \multirow{3}{*}{$\begin{array}{c}\text { Sex } \\
\text { of } \\
\text { infant }\end{array}$} \\
\hline & & & \multicolumn{3}{|c|}{ Hematocrit } & \multicolumn{3}{|c|}{ Total base } & \multirow{2}{*}{$\begin{array}{c}\text { Venous } \\
\text { total } \\
\text { base }\end{array}$} & \multirow{2}{*}{$\underset{\text { crit }}{\text { Hemato- }}$} & \multirow{2}{*}{$\begin{array}{c}\text { Days } \\
\text { after } \\
\text { delivery }\end{array}$} & \\
\hline & & & $\underset{\text { arterial }}{\text { Infant }}$ & $\begin{array}{l}\text { Infant } \\
\text { venous }\end{array}$ & $\begin{array}{c}\text { Maternal } \\
\text { venous }\end{array}$ & $\begin{array}{l}\text { Infant } \\
\text { arterial }\end{array}$ & $\begin{array}{l}\text { Infant } \\
\text { venous }\end{array}$ & $\begin{array}{c}\text { Maternal } \\
\text { venous }\end{array}$ & & & & \\
\hline $\begin{array}{r}1 \\
2 \\
3 \\
4 \\
5 \\
6 \\
7 \\
8 \\
9 \\
10 \\
11 \\
12 \\
13 \\
14 \\
15 \\
16 \\
17 \\
18 \\
19 \\
20 \\
21 \\
22 \\
23 \\
24 \\
25 \\
26 \\
27 \\
28 \\
29 \\
30\end{array}$ & $\begin{array}{c}\text { years } \\
21 \\
27 \\
39 \\
16 \\
19 \\
20 \\
34 \\
18 \\
25 \\
38 \\
18 \\
21 \\
38 \\
30 \\
20 \\
26 \\
25 \\
25 \\
25 \\
31 \\
22 \\
37 \\
23 \\
20 \\
21 \\
23 \\
33 \\
17 \\
26 \\
32\end{array}$ & $\begin{array}{r}1 \\
1 \\
5 \\
1 \\
1 \\
1 \\
1 \\
1 \\
3 \\
3 \\
1 \\
1 \\
2 \\
1 \\
1 \\
3 \\
2 \\
2 \\
3 \\
3 \\
1 \\
13 \\
1 \\
1 \\
1 \\
2 \\
8 \\
1 \\
2 \\
2\end{array}$ & $\begin{array}{c}\text { per } \\
\text { cent } \\
53.8 \\
53.2 \\
64.2 \\
64.4 \\
47.5 \\
62.4 \\
64.2 \\
55.6 \\
65.6 \\
57.8 \\
57.0 \\
53.4 \\
55.8 \\
55.8 \\
52.0 \\
60.6 \\
50.0 \\
51.8 \\
54.4 \\
58.6 \\
63.4 \\
60.4 \\
51.4 \\
63.0 \\
50.0 \\
60.2 \\
\end{array}$ & 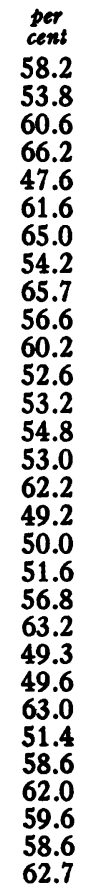 & $\begin{array}{l}\text { per } \\
\text { cent } \\
42.9 \\
44.9 \\
46.2 \\
44.1 \\
38.2 \\
44.8 \\
43.5 \\
41.6 \\
45.4 \\
38.8 \\
43.1 \\
39.7 \\
50.8 \\
41.0 \\
44.5 \\
46.0 \\
42.4 \\
41.8 \\
42.2 \\
37.0 \\
40.4 \\
38.9 \\
40.5 \\
40.2 \\
47.8 \\
45.7 \\
40.6 \\
40.0 \\
37.6 \\
40.6\end{array}$ & $\begin{array}{c}\text { m.eq. } \\
\text { per liter } \\
\\
143.7 \\
138.2 \\
149.4 \\
145.0 \\
146.5 \\
147.3 \\
145.2 \\
145.8 \\
141.0 \\
148.5 \\
145.7 \\
143.3 \\
142.0 \\
148.9 \\
146.7 \\
146.7 \\
143.6 \\
145.7 \\
155.0 \\
155.9 \\
153.6 \\
149.1 \\
148.7 \\
151.4 \\
153.0 \\
153.4 \\
151.8\end{array}$ & $\begin{array}{c}\text { m.eq: } \\
\text { per liter } \\
143.9 \\
143.8 \\
139.8 \\
147.5 \\
144.0 \\
143.0 \\
146.8 \\
137.6 \\
144.6 \\
143.2 \\
148.0 \\
143.0 \\
145.5 \\
139.1 \\
148.0 \\
148.3 \\
145.9 \\
142.7 \\
144.3 \\
154.2 \\
153.9 \\
152.8 \\
148.5 \\
146.5 \\
153.1 \\
149.1 \\
150.6 \\
154.2 \\
150.9 \\
152.7\end{array}$ & $\begin{array}{c}\text { m.eq. } \\
\text { per liter } \\
145.8 \\
145.5 \\
146.6 \\
142.0 \\
146.0 \\
141.4 \\
144.2 \\
138.1 \\
137.9 \\
139.5 \\
147.2 \\
139.6 \\
142.7 \\
143.7 \\
142.9 \\
144.8 \\
144.8 \\
140.8 \\
142.9 \\
147.7 \\
148.3 \\
145.2 \\
145.2 \\
141.7 \\
144.9 \\
150.7 \\
146.9 \\
147.9 \\
150.5 \\
151.5\end{array}$ & $\begin{array}{l}149.8 \\
148.7 \\
147.6 \\
148.4 \\
146.1 \\
149.6 \\
149.2 \\
155.9 \\
\\
149.8 \\
153.2 \\
153.2 \\
153.3 \\
151.8\end{array}$ & $\begin{array}{l}42.7 \\
41.1 \\
32.8 \\
47.3 \\
41.9 \\
36.1 \\
47.3 \\
\\
36.8\end{array}$ & $\begin{array}{r}8 \\
7 \\
8 \\
7 \\
8 \\
8 \\
5 \\
9 \\
\\
\\
5 \\
9 \\
8 \\
12 \\
9\end{array}$ & 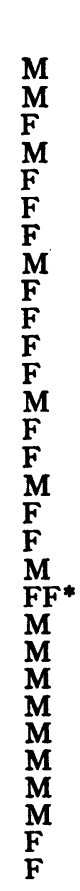 \\
\hline \multicolumn{3}{|c|}{ Average } & 57.6 & 57.0 & 42.3 & 147.5 & 146.8 & 144.6 & 150.5 & 41.8 & & \\
\hline \multicolumn{3}{|c|}{ Average deviation } & \pm 4.4 & \pm 4.8 & \pm 2.6 & \pm 3.5 & \pm 3.2 & \pm 2.5 & \pm 2.3 & \pm 3.7 & & \\
\hline
\end{tabular}

* Total base on twin " B" only. 
(Patient 3) was a maternal total base value encountered that was significantly higher than that of the infant arterial or venous plasma. This woman was 39 years old and a para 5 . Yet age and the number of previous child bearings does not appear responsible because in Patient 22, age 38 and para 13, the more general total base relationships were found to exist. In twelve other patients (Patients 1, 2, 5, 10,11, 13, 14, 17, 18, 26,29 , and 30 ) the total base of mother and child were found to be equal within the limits of experimental error. The ages of these patients varied from 19 to 38 years, and the number of births varied from 1 to 3 children each. In the other 16 cases in which the patients' ages varied from 16 to 33 years and the number of children born varied from 1 to 8 , the total base of the infant plasma exceeded the maternal value by an amount greater than the experimental error of determination. The values for infant arterial and venous plasma were consistently close together and no significant difference in base between them was apparent.

Three unreported values for total base on the infant arterial plasma were due in 2 cases to insufficient material for analysis and in the third, to contamination of the sample. One patient, Number 8, had rheumatic heart disease without apparent decompensation and on her the values reported are quite inconsistent, the plasma from the umbilical artery appearing to have a higher total base than either the maternal or infant venous plasma. The only conceivable explanation for this anomaly is inadvertent confusion of the sampling tubes at the time the blood was obtained.

In two other cases pregnancy was complicated by pathological symptoms. In the one there was a history of pylorospasm, while in the other there was a toxemia with edema extending from the feet to the knees. No significant difference between these and the other cases could be noted. There was one pair of twins, the first of whom was unfortunately cyanotic when born, so blood collection from this infant was not attempted. The values obtained on the second twin and its mother were not significantly different from the others.

The mean values for maternal and infant arterial and infant venous plasma were found to be $144.6,147.5$, and 146.8 m.eq. respectively. The values for fetal plasma are of the same magnitude as those of Eastman, Geiling, and DeLawder (3) who observed the fetal total base to be about 148.0 m.eq. per liter of plasma. Dieckmann and Wegner (9) have reported analyses of total base in the maternal organism during gestation, but values at term are not separately given. Since the total base appears to change during pregnancy, ${ }^{1}$ a mean value for total base during gestation would not be comparable with values obtained at term.

The authors were also interested to find out what changes take place in the maternal total base after delivery. These values, which are also reported in Table II, indicate that in every instance a definite increase in total base concentration of the mother has already taken place between the time of delivery and from 5 to 12 days after delivery. Whether this is a result of loss of fluid or of an added intake or diminished output of minerals or both, is at present a moot question.

Investigators are agreed that an increase in blood volume takes place during pregnancy. Oberst and Plass (8) found that during pregnancy the water content of the blood plasma increases, but at parturition has decreased to below the pre-pregnant level; in the puerperium there is a slight rise in the water content. On this basis, the values for maternal total base at parturition and in the puerperium are not to be accounted for by changes in the water content of the plasma alone.

The frequent finding of definite differences in concentration of total base in maternal and infant plasma points to some unidentified factor by which an excess of base may be retained in the fetal circulation. It may be that the variations of total base encountered in the fetal circulation compensate osmotically for the relatively smaller concentration of plasma protein, but simultaneous determinations of total base and total plasma protein concentration in the two circulations would be required in order to settle this point.

\section{SUMMARY}

In a study of 30 parturient women and their respective newborn children the mean maternal total base per liter of plasma was found to be $144.6 \pm 2.5$ m.eq.; infant arterial plasma 147.5

\footnotetext{
1 Unpublished data of the authors.
} 
\pm 3.5 m.eq.; infant venous plasma $146.8 \pm 3.2$ m.eq. The mean difference between maternal and infant arterial plasma was found to be $2.2 \mathrm{~m} . e q$. Differences between the mean infant arterial and mean venous values are less than the experimental error. Correlations of values obtained with previous history, age, number of previous children, or sex of infant were not apparent.

In 13 of these cases, the plasma total base of the mother was followed after delivery, and in every instance there was a definite increase in its concentration during the puerperium.

\section{BIBLIOGRAPHY}

1. Stander, H. J., and Tyler, Margaret, The moisture and ash of maternal and fetal blood. Surg., Gynec. and Obst., 1920, 31, 276.

2. Lévy-Solal, E., Dalsace, J., and Gutman, C., Recherches biochemiques sur le rôle du placenta. Compt. rend. Soc. de Biol., 1934, 115, 269.

3. Eastman, N. J., Geiling, E. M. K., and DeLawder, A. M., Fetal blood studies. IV. The oxygen and carbon dioxide dissociation curves of fetal blood. Bull. Johns Hopkins Hosp., 1933, 53, 246.

4. Pommerenke, W. T., Placental interchange. I. On the concentration of certain nitrogenous substances in the blood, before and after passing through the placenta. J. Clin. Invest., 1936, 15, 485.

5. Keys, A., The determination of total base in blood and other biological fluids by the electrodialysis method of Adair and Keys. J. Biol. Chem., 1936, 114, 449.

6. Bock, A., Uber das Verhalten des Ammoniaks im Blute von Schwangeren, über seine Ursprungssubstanz und seine Rolle bei der Neutralitätsregulierung. Arch. f. Gynäk., 1930, 140, 1.

7. Marx, Helmut, Der Wasserhaushalt des gesunden und kranken Menschen. J. Springer, Berlin, 1935, p. 31.

8. Oberst, F. W., and Plass, E. D., Water concentration of the blood during pregnancy, labor, and the puerperium. Am. J. Obst. and Gynec., 1936, 31, 61.

9. Dieckmann, W. J., and Wegner, C. R., Studies of the blood in normal pregnancy. V. Conductivity, total base, chloride, and acid-base equilibrium. Arch. Int. Med., 1934, 53, 527. 